\title{
SOSIALISASI KEWASPADAAN TERHADAP PENYAKIT TIDAK MENULAR KEPADA MASYARAKAT DESA JEMBUNGAN, BOYOLALI
}

\author{
Socialization of Awareness to Non-communicable Diseases to The Community of Jembungan \\ Village, Boyolali
}

\author{
Budi Hernawan, Faiz Maulana, Lina Amalia \\ Fakultas Kedokteran Universitas Muhammadiyah Surakarta \\ Korespondensi: Budi Hernawan, email: bh235@ums.ac.id
}

\begin{abstract}
ABSTRAK
Penyakit tidak menular (PTM) mempunyai angka mortalitas 63\% yang menjadi penyebab kematian di seluruh dunia. Modernisasi menyebabkan perubahan gaya hidup tidak sehat seperti diet tidak sehat, olahraga kurang, dan merokok. Gaya hidup tidak sehat tersebut menyebabkan peningkatan tekanan darah, gula darah, kadar lemak darah, serta obesitas, yang pada akhirnya meningkatkan prevalensi penyakit jantung, dan pembuluh darah, penyakit paru obstruksi kronik, dan kanker. Pengabdian masyarakat ini bertujuan untuk meningkatkan pengetahuan mengenai definisi dari penyakit tidak menular, faktor risiko penyakit tidak menular, penyebab timbulnya penyakit tidak menular, dan pencegahan terhadap penyakit tidak menular. Metode pelaksanaan dengan penyuluhan, dengan pretest sebelum penyuluhan dan posttest setelah penyuluhan. Hasil posttest menunjukkan adanya peningkatan 50\% mengenai pengetahuan penyakit tidak menular. Simpulan dari sosialisasi yaitu terjadi peningkatan pengetahuan masyarakat mengenai penyakit tidak menular.
\end{abstract}

\section{Kata kunci: konseling, penyakit tidak menular, pengetahuan}

\section{ABSTRACT}

Non-communicable diseases (NCD) have a mortality rate of $63 \%$ which is the cause of death worldwide. Modernization causes changes in unhealthy lifestyles such as unhealthy diets, lack of exercise, and smoking. These unhealthy lifestyles lead to an increase in blood pressure, blood sugar, blood fat levels, and obesity, which in turn increase the prevalence of heart disease, and blood vessels, chronic obstructive pulmonary disease, and cancers. This community service aims to increase knowledge about the definition of non-communicable diseases, non-communicable disease risk factors, causes of non-communicable diseases, and prevention of noncommunicable diseases. Methods of implementation by counseling, with pretest before counseling and posttest after counseling. Posttest results showed a 50\% increase in knowledge of non-communicable diseases. The conclusion of the socialization is an increase in public knowledge about non-communicable diseases.

Keywords: counseling, non-communicable diseases, knowledge 


\section{PENDAHULUAN}

Umur harapan hidup penduduk indonesia telah meningkat dari 54,4 pada tahun 1980, menjadi 69,8 pada tahun 2012 dan menjadi tolak ukur keberhasilan pembangunan kesehatan di Indonesia dalam 3 dekade terakhir (Badan Pusat Statistik, 2013). Angka morbiditas penduduk Indonesia terhadap penyakit menular sudah mengalami penurunan, namun angka morbiditas dan mortalitas terhadap penyakit tidak menular meningkat tajam (Riskesdas, 2014), sehingga sekarang Indonesia mengalami tantangan ganda terhadap masalah kesehatan, yaitu tantangan terhadap penyakit menular, meski sudah menurun angka morbiditasnya, juga tantangan terhadap penyakit tidak menular.

Penyakit tidak menular (PTM) mempunyai angka mortalitas $63 \%$ yang menjadi penyebab kematian di seluruh dunia. Modernisasi menyebabkan perubahan gaya hidup tidak sehat seperti diet tidak sehat, olahraga kurang, dan merokok. Gaya hidup tidak sehat tersebut menyebabkan peningkatan tekanan darah, gula darah, kadar lemak darah, serta obesitas, yang pada akhirnya meningkatkan prevalensi penyakit jantung, dan pembuluh darah, penyakit paru obstruksi kronik, dan berbagai kanker (WHO, 2014).

Penyakit tidak menular merupakan penyakit-penyakit yang sifatnya menahun/kronik, tidak menular, dan tatalaksana pengobatannya lama dan membutuhkan biaya yang mahal. Penyakit tidak menular dapat terjadi pada semua organ, sehingga diagnosis penyakit tidak menular bermacam-macam (Kemenkes, 2016).

\section{TUJUAN DAN MANFAAT}

Kegiatan ini bertujuan untuk meningkatkan pengetahuan mengenai definisi dari penyakit tidak menular, faktor risiko penyakit tidak menular, penyebab timbulnya penyakit tidak menular, pencegahan terhadap penyakit tidak menular. Diharapkan dengan adanya kegiatan ini pengetahuan masyarakat menjadi meningkat serta semakin waspada terhadap penyakit tidak menular sehingga mampu mewujudkan perubahan perilaku dari masyarakat desa Jembungan menuju masyarakat yang sehat. Sehingga rata-rata usia pada masyarakat desa Jembungan pada khususnya akan meningkat dan rata-rata usia masyarakat di Indonesia pada umumnya akan meningkat juga. 


\section{METODE PELAKSANAAN}

Sosialisasi dilakukan dengan metode penyuluhan. Didahului dengan pretest, kemudian penyuluhan mengenai penyakit tidak menular, macam-macamnya serta cara pencegahannya. Kemudian dilanjutkan sesi diskusi tanya jawab. Dilakukan posttest pada sesi yang terakhir. Analisis keberhasilan penyuluhan menggunakan nilai pre test dan post test.

\section{HASIL DAN DISKUSI}

Kegiatan sosialisasi kewaspadaan terhadap penyakit tidak menular kepada masyarakat desa Jembungan, dilaksanakan pada hari Ahad tanggal 8 Juli 2018 di balai desa Jembungan, kecamatan Banyudono, kabupaten Boyolali yang dihadiri oleh masyarakat desa Jembungan dan sekitarnya. Masyarakat yang hadir berjumlah 59 orang, terdiri dari 23 orang laki-laki dan 46 orang wanita. Target sasaran sosialisasi pada masyarakat usia lebih dari 25 tahun, dikarenakan penyakit tidak menular memang bisa terjadi pada semua orang, terutama pada usia dewasa muda sampai usia tua.

$$
\text { Masyarakat desa Jembungan, }
$$

kecamatan Banyudono, kabupaten Boyolali termasuk daerah dengan risiko tinggi terjadinya penyakit tidak menular. Di daerah ini, banyak terdapat penyakit hipertensi, penyakit paru obstruksi kronis, dan diabetes melitus. Penyakit tersebut terjadi pada masyarakat usia 50 tahun ke atas, sehingga menurunkan rata-rata usia pada masyarakat desa Jembungan.

Kegiatan sosialisasi kewaspadaan terhadap penyakit tidak menular kepada masyarakat desa Jembungan memberikan dampak peningkatan pengetahuan dari masyarakat. Hasil rerata skor pretes didapatkan 3,41 , sedangkan rerata skor post tes didapatkan 5,25 .

Pemerintah Indonesia telah melakukan berbagai upaya dalam pencegahan dan penanggulang penyakit tidak menular. Pemerintah mengadopsi upaya dari WHO, yaitu melalui identifikasi faktor risiko bersama (Common Risk Factors). Pada tingkat komunitas sudah dibentuk Pos Pembinaan Terpadu (Posbindu) penyakit menular. Kegiatan Pospindu adalah identifikasi faktor risiko, penyuluhan, dan kegiatan bersama komunitas untuk membawa masyarakat dalam mewujudkan perilaku hidup bersih dan sehat (PHBS).

Sesuai dengan misi dari pemerintah tersebut, maka diadakan kegiatan sosialisasi kewaspadaan terhadap penyakit tidak menular 
kepada masyarakat desa Jembungan, kecamatan

Banyudono, kabupaten Boyolali.

\section{SIMPULAN DAN SARAN}

Simpulan dari penyuluhan ini bahwa

dengan kegiatan penyuluhan ini terjadi

peningkatan pengetahuan pada masyarakat desa

Jembungan tentang penyakit tidak menular.

Evaluasi berkelanjutan, akan dilakukan

sosialisasi secara berkala 1 bulan sekali di desa

binaan Jembungan oleh dosen dan mahasiswa

FK UMS, bertujuan supaya pengetahuan

masyarakat tentang kesehatan akan bertambah.

Tidak hanya mengenai penyakit tidak menular,

tetapi juga penyakit-penyakit lainnya.

Diharapkan mampu mewujudkan perubahan perilaku dari masyarakat desa Jembungan menuju masyarakat yang sehat. Sehingga ratarata usia pada masyarakat desa Jembungan pada khususnya akan meningkat dan rata-rata usia masyarakat di Indonesia pada umumnya juga akan meningkat.

\section{DAFTAR PUSTAKA}

Badan Pusat Statistik. 2013. Statistik Indonesia Tahun 2013. Jakarta: Badan Pusat Statistik.

DEPKES, 2014. Riset Kesehatan Dasar. Jakarta: Badan Penelitian dan Pengembangan Kesehatan Kementrian Kesehatan RI.

Kemenkes. 2016. Buku Pedoman Teknis Penyelenggaraan Pencegahan Penyakit Tidak Menular. Jakarta: Kemenkes RI

WHO. 2014. Global Status Report on Non Communicable Diseases. Geneva: WHO 